\title{
Evidence and practices of the use of next generation sequencing in patients with undiagnosed autosomal dominant cerebellar ataxias: a review
}

\author{
Evidências e práticas do uso do sequenciamento de nova geração em pacientes \\ com ataxias cerebelares autossômicas dominantes não diagnosticadas: uma revisão \\ Luiz Eduardo NOVIS', Mariana SPITZ1', Marcia JARDIM', Salmo RASKIN², Hélio A. G. TEIVE
}

\begin{abstract}
Autosomal dominant cerebellar ataxias (ADCA) are heterogeneous diseases with a highly variable phenotype and genotype. They can be divided into episodic ataxia and spinocerebellar ataxia (SCA); the latter is considered the prototype of the ADCA. Most of the ADCA are caused by polyglutamine expansions, mainly SCA 1, 2, 3, 6, 7, 17 and Dentatorubral-pallidoluysian atrophy (DRPLA). However, 30\% of patients remain undiagnosed after testing for these most common SCA. Recently, several studies have demonstrated that the new generation of sequencing methods are useful for the diagnose of these patients. This review focus on searching evidence on the literature, its usefulness in clinical practice and future perspectives.
\end{abstract}

Keywords: next generation sequencing; autosomal dominant cerebellar ataxias; spinocerebellar ataxias.

RESUMO

As ataxias cerebelares autossômicas dominantes (ACAD) são doenças heterogêneas com fenótipo e genótipo altamente variáveis. Podem ser divididas em ataxia episódica e ataxia espinocerebelar (SCA), sendo este último considerado o protótipo do ACAD. A maior parte das ACAD são causadas por expansões de poliglutaminas, principalmente SCA 1, 2, 3, 6, 7, 17 e atrofia dentatorubro-palidoluisiana (DRPLA). No entanto, 30\% dos pacientes permanecem sem diagnóstico após o teste para essas SCA mais comuns. Recentemente, vários estudos têm demonstrado que a nova geração de métodos de sequenciamento são ferramentas úteis para o diagnóstico desses pacientes. Esta é uma revisão sistemática da literatura, com foco em sua utilidade na prática clínica e em perspectivas futuras.

Palavras-chave: sequenciamento de nova geração; ataxias cerebelares autossômicas dominantes; ataxias espinocerebelares.

\section{INTRODUCTION}

Autosomal dominant cerebellar ataxias (ADCA) comprise a group of inherited cerebellar ataxias that are clinically and genetically heterogeneous ${ }^{1}$. They can be caused by several mechanisms, such as expansion of short tandem repeats (STR), mainly trinucleotide repeat expansions (TRE), and less commonly, single nucleotide variation and short insertions and deletions (indels). The most studied mechanism related to TRE is the one caused by expanded polyglutamine. These proteins have a pathological gain of function with a subsequent neuronal toxic effect. In these cases, there may be an anticipation phenomenon, which is characterized by increasingly early onset of symptoms as the disease is transmitted from one generation to the next. Clinically ADCA are progressive neurodegenerative diseases that share cerebellar ataxia as the core symptom, associated with progressive cerebellar atrophy. However, other brain regions, such as the brainstem, may also be involved. Within this group, we will herein emphasize the

\footnotetext{
${ }^{1}$ Universidade do Estado do Rio de Janeiro, Hospital Universitário Pedro Ernesto, Serviço de Neurologia, Rio de Janeiro RJ, Brazil. ${ }^{2}$ Laboratório Genetika, Curitiba PR, Brazil.

${ }^{3}$ Universidade Federal do Paraná, Departamento de Clínica Médica, Serviço de Neurologia, Setor de Distúrbios do Movimento, Hospital das Clínicas, Curitiba PR, Brazil.

Luiz Eduardo NOVIS (iD https://orcid.org/0000-0003-1479-2953; Mariana SPITZ iD https://orcid.org/0000-0001-7548-2313;

Marcia JARDIM (iD https://orcid.org/0000-0003-1784-6857; Salmo RASKIN (iD) https://orcid.org/0000-0002-7191-0592;

Hélio A. G. TEIVE (iD https://orcid.org/0000-0002-4045-1178

Correspondence: Luiz Eduardo Novis de Farias; E-mail: luizeduardonovis@hotmail.com

Conflict of interest: There is no conflict of interest to declare.
}

Received on September 03, 2019; Received in its final form on November 18, 2019; Accepted on January $28,2020$. 
spinocerebellar ataxias (SCA), often used as a synonym for autosomal dominant ataxias.

The SCA has a wide range of neurological symptoms, including gait and appendicular ataxia, dysarthria, oculomotor abnormalities of cerebellar and supranuclear origin, retinopathy, optic atrophy, spasticity, extrapyramidal, peripheral neuropathy, sphincter disorders, cognitive changes, and epilepsy ${ }^{1,2,3}$. Clinical diagnosis is challenging due to large phenotypic and genotypic variability. To facilitate clinical evaluation, Harding et al. suggested a classification into three subtypes: ADCA type 1, characterized by cerebellar ataxia, optic atrophy, ophthalmoplegia, extrapyramidal symptoms, pyramidal signs, peripheral neuropathy, amyotrophy and dementia; ADCA type 2, when CA is associated with retinal degeneration; ADCA type 3, composed of "pure" cerebellar ataxias $^{4}$ (Table 1). Currently, the classification of SCA is based on the identified mutation/expansion, also known as clinical-genetic classification ${ }^{5}$. Forty-eight SCA subtypes have been described to date ${ }^{6,7,8}$ and this number tends to grow in the following years, thanks to the availability of new DNA sequencing techniques. Table 2, adapted from a review from Sullivan et al. ${ }^{6}$, shows the main clinical characteristics of each SCA subtype.

In this review, we will address the challenges in diagnosis of spinocerebellar ataxias, the recent diagnostic tools that are helpful when we have a patient with negative DNA test (herein called "negative ataxias") and future perspectives in the field.

\section{EPIDEMIOLOGICAL CONTEXT}

The prevalence of hereditary ataxias in general has been little studied. A meta-analysis by Ruano et al. ${ }^{9}$, which included 22 studies from 16 countries with more than 14,500 patients, showed that the average prevalence of ADCA is $2.7 / 100,000$. However, it is worth mentioning that this prevalence is variable in different regions. International studies have been conducted to assess the prevalence of ADCA around the world. A prevalence of $3 / 100,000$ cases was found in the Netherlands ${ }^{10}$, 4.2/100,000 in Southern Norway ${ }^{11}$ and 5.6/100,000 in Portugal ${ }^{12}$. In all studies, spinocerebellar ataxia type 3 (SCA3 or MachadoJoseph disease) is the most commonly mutation found.

Table 1. Autossomal dominant cerebellar ataxia clinical classification.

\begin{tabular}{|c|c|}
\hline ADCA 1 & $\begin{array}{l}\text { SCA 1-4, 8, 12-14, 15, 17-22, 25, 27, 28, 31, } \\
\text { 32, 34-37, 38, 42-44, 46-48, DRPLA, DNMT1 }\end{array}$ \\
\hline ADCA 2 & SCA 7 \\
\hline ADCA 3 & SCA $5,6,10,11,23,26,30,37,41,45$ \\
\hline
\end{tabular}

Source: adapted from Sullivan et al. ${ }^{6}$

ADCA: autossomal dominant cerebellar ataxia; SCA: spinocerebellar ataxia; DRPLA: dentatorubral-pallidoluysian atrophy; DNMT1: DNA methyltransferase.
In Brazil it is believed that the great epidemiological variability is due to the founder effect of different geographical regions ${ }^{3,12,13,14,15,16}$. Worldwide, several epidemiological studies have demonstrated a higher frequency of SCA 1 in countries such as Italy and India; SCA 2 in Mexico, Cuba, India and Canada; SCA 6 in Australia and Canada; SCA 8 in Finland, and DRPLA in Japan (Table 3) 2,11,12,13,14,15,16,17,18,19,20. The main subtype found in Brazil is SCA3, and cases of SCA 1, 2, 6, 7 and 10 occur less frequently; other types are considered very rare. Jardim et al. ${ }^{21}$ conducted a research on ADCA in Southern Brazil evaluating 66 cases of SCA. The authors concluded that the proportion of cases of SCA 3 was very high, suggesting an Azorean founding effect. The frequency of SCA 3 in the region was $1.8 / 100,000$, versus $0.2 / 100,000$ for other forms of autosomal dominant ataxia. Cintra et al. ${ }^{22}$ found an even higher prevalence in the region of São Paulo, 5/100,000, considered to date the highest prevalence of SCA 3 found in Brazil. In a study with 104 families with SCA, Teive et al..$^{23}$ found a high prevalence for SCA 3 (72.46\%) followed by SCA 10 (11.6\%). Braga-Neto et al. ${ }^{24}$ evaluated 45 families from the Northeast of the country with ataxia and identified a high consanguinity rate $(40.7 \%)$. In this series, a higher prevalence of recessive autosomal ataxias (33.3\%) was identified compared to dominant autosomal ataxias (6.6\%), in contrast to other Brazilian epidemiological studies. However, epidemiological studies from the north of the country are scarce, and further studies are needed to assess the prevalence of hereditary ataxias in other regions of the country. Table 4 shows the frequencies of SCA in the Brazilian territory $21,22,23,25,26,27,28,29,30,31$.

Table 2. Phenotype characteristics of each spinocerebellar ataxia.

\begin{tabular}{|c|c|}
\hline Associated clinical features & Genetic subtypes \\
\hline Peripheral neuropathy & $1,2,3,4,18,25,38,43,46$ \\
\hline Pyramidal signs & $1,3,7,8,10,14,15,17,35,40,43$ \\
\hline Dystonia & $3,14,17,20,35$ \\
\hline Myoclonus & 14 \\
\hline Parkinsonism & $2,3,10,14,17,19 / 22,21$ \\
\hline Tremor & $12,15,27$ \\
\hline Chorea & $17,27, \mathrm{DRPLA}{ }^{*}$ \\
\hline Cognitive impairment & $\begin{array}{c}2,8,13,17,19 / 22 \\
21,36,44,48, \text { DRPLA }\end{array}$ \\
\hline Psychiatric symptoms & $2,17,48$ \\
\hline Ophthalmoplegia & $2,3,28,40$ \\
\hline Visual impairment & 7 \\
\hline Face/tongue fasciculation & 36 \\
\hline Ichthyosiform plaques & 34 \\
\hline Seizures & 10, 19/22, ATN 1** \\
\hline Narcolepsy & DNMT1*** \\
\hline Hearing loss & 31, 36, DNMT1 \\
\hline
\end{tabular}




\section{MOLECULAR DIAGNOSTIC CHALLENGES IN ADCA}

The diagnostic investigation of patients with ADCA involves PCR (polymerase chain reaction) technique, and is based on in-vitro amplification of specific regions of the DNA, allowing the detection of nucleotide expansions, which are the substrate for the most common ADCA worldwide ${ }^{9,10,14,22,25}$. Approximately $30 \%$ of the patients investigated for ADCA by the conventional method (PCR) have negative results.

The absence of a diagnosis can be very frustrating for both the patient and the physician. Obtaining a diagnosis can be an important factor of psychological impact, prognosis, genetic counseling, preimplantation genetic diagnosis and family diagnosis. In addition, it may be essential for the development of specific treatments based on a better understanding of the mutation ${ }^{32}$.

When initial DNA investigation fails, the next step would be to conduct a gene-to-gene search, which is considered a time-consuming and expensive method. But nowadays, with the fantastic advance in the development of molecular genetic techniques, with next-generation sequencing (NGS) technology, it is possible to carry out sequencing of several genes simultaneously, saving time and costs. Each NGS technique has its advantages and disadvantages, which must be weighed to choose the ideal method for the diagnosis.

\section{GENETIC TECHNOLOGY EVOLUTION: SOLUTION OR ADDITIONAL PROBLEMS?}

In 1977, Frederick Sanger and colleagues developed a DNA sequencing method based on chain-termination inhibitors. In this method, a DNA template is replicated using a primer and a DNA polymerase that incorporates dideoxynucleotides in the sequence synthesis, causing its early termination. After multiple reactions, DNA fragments of different lengths are formed and can be read by an automated apparatus, providing DNA sequencing ${ }^{33}$.

Compared to Sanger sequencing, considered a gold standard for genetic sequencing, NGS is capable of sequencing

Table 3. Prevalence of spinocerebellar ataxias across the world.

\begin{tabular}{|c|c|c|c|c|c|c|c|c|c|c|c|c|c|c|}
\hline Country & $\mathrm{n}$ & SCA1 & SCA2 & SCA3 & SCA6 & SCA7 & SCA8 & SCA 10 & SCA 12 & SCA14 & SCA 17 & DRPLA & und. & References \\
\hline Mexico & 108 & ND & 45,4 & 12 & ND & 7,4 & ND & 13,9 & ND & NR & 2,8 & ND & 18 & Alonso et al. ${ }^{15}$ \\
\hline Portugal & 199 & ND & 2,5 & 80,5 & $<1$ & 1,25 & 1 & ND & ND & $<1$ & $<1$ & 8,5 & $26,5^{\star}$ & Coutinho et al.12 \\
\hline Cuba & 177 & ND & 86,8 & 1,2 & ND & ND & NP & NP & NR & NP & ND & ND & 12 & Velázquez et al. $2009^{16}$ \\
\hline Italy & 225 & 21 & 24 & $<1$ & $<1$ & $<1$ & $<1$ & ND & ND & NP & $<1$ & $<1$ & 41 & Brusco et al..$^{14}$ \\
\hline Australia & 88 & 16 & 6 & 12 & 17 & 2 & NP & NP & NR & NP & NP & ND & 41 & Storey et al. ${ }^{13}$ \\
\hline China & 85 & 4,7 & 5,9 & 48,2 & ND & ND & NP & NP & NR & NP & NP & ND & 41,2 & Tang et al. ${ }^{17}$ \\
\hline $\begin{array}{l}\text { Japan } \\
\text { (Honshu) }\end{array}$ & 101 & ND & 5,9 & 33,7 & 5,9 & NP & NP & NP & NR & NP & NP & 19,8 & $?$ & Watanabe et al. ${ }^{18}$ \\
\hline Finland & 49 & 4 & 2 & ND & 2 & 12 & 18 & ND & ND & NP & 2 & ND & 61 & Juvonen et al. ${ }^{19}$ \\
\hline Germany & 77 & 9 & $10 \%$ & 42 & 22 & NP & NP & NP & NR & NP & NP & NP & 17 & Schöls et al. ${ }^{2}$ \\
\hline Norway & 48 & $<1$ & $<1$ & $<1$ & ND & NP & NP & NP & NR & NP & NP & NP & 92 & Erichsen et al.11 \\
\hline India & 77 & 15,6 & 24,7 & 2,6 & ND & 2,6 & ND & NP & 6,5 & NP & NP & ND & 48 & Srivastava et al. ${ }^{20}$ \\
\hline
\end{tabular}

Results are displayed in percent. ND: not detected; NP not performed; und.: undetermined; * of 174 undiagnosed patients, only $87.3 \%$ (152 patients) underwent the adopted genetic test, resulting in $26.48 \%$ of patients with unidentified mutations.

Table 4. Prevalence of spinocerebellar ataxia in Brazil.

\begin{tabular}{|c|c|c|c|c|c|c|c|c|c|c|c|c|}
\hline Reference & $n$ & SCA1 & SCA2 & SCA3 & SCA6 & SCA7 & SCA 8 & SCA10 & SCA12 & SCA17 & DRPLA & und. \\
\hline Silveira ${ }^{28}$ & 67 & $5 \%$ & NP & $55 \%$ & NP & NP & NP & NP & NP & NP & $2 \%$ & $61,20 \%$ \\
\hline Lopes-Cendes $^{29}$ & 54 & $6 \%$ & $9 \%$ & $44 \%$ & NP & NP & NP & NP & NP & NP & NP & $40 \%$ \\
\hline Jardim $^{21}$ & 52 & ND & ND & $92 \%$ & ND & $2 \%$ & * & NP & NP & NP & ND & $6 \%$ \\
\hline $\operatorname{Trott}^{30}$ & 114 & ND & $4,40 \%$ & $84,20 \%$ & $1,80 \%$ & ND & NP & $1,80 \%$ & NP & ND & ND & $6 \%$ \\
\hline Freund $^{31}$ & 115 & ND & $5,20 \%$ & $21,70 \%$ & $0,80 \%$ & $2,60 \%$ & NP & NP & NP & NP & NP & $69,50 \%$ \\
\hline Teive ${ }^{23}$ & 104 & $2,90 \%$ & $7,20 \%$ & $72,50 \%$ & ND & $4,30 \%$ & NP & $11,60 \%$ & NP & NP & NP & $33,70 \%$ \\
\hline Cintra ${ }^{22}$ & 150 & $6 \%$ & $3 \%$ & $81 \%$ & $1,50 \%$ & $7 \%$ & $0,80 \%$ & $0,80 \%$ & NP & NP & NP & $12,70 \%$ \\
\hline Castilhos $^{25}$ & 359 & $5,20 \%$ & $7,80 \%$ & $59,60 \%$ & $1,40 \%$ & $5,60 \%$ & NP & $3,30 \%$ & ND & ND & ND & $18,10 \%$ \\
\hline Teive ${ }^{26}$ & 460 & $4.3 \%$ & $6.5 \%$ & $45.7 \%$ & $0.6 \%$ & $1.8 \%$ & NP & $18.3 \%$ & NP & NP & NP & $22.8 \%$ \\
\hline Braga-Neto 27 & 487 & $4,30 \%$ & $11,50 \%$ & $53,60 \%$ & $1,20 \%$ & $4,50 \%$ & NP & $2,20 \%$ & $0,20 \%$ & ND & $0,20 \%$ & $22.3 \%$ \\
\hline
\end{tabular}

und.: undetermined. 
several genes (or DNA templates) simultaneously, providing a large amount of information in an accurate and fast way, whereas Sanger sequencing, despite being reliable, can sequence only one gene at a time, making investigation timeconsuming and costly ${ }^{34}$.

When one suspects of SCA and performs a DNA test such as Whole Exome Sequencing (WES), about $64 \%$ of the diagnoses made by this method are from mutations traditionally known to be responsible for causing hereditary ataxias, while $30 \%$ are from newly discovered genes and $6 \%$ from genes that were not typically considered to cause ataxia ${ }^{35}$.

In practical terms, NGS can be employed in three ways:

- Targeted sequencing panels (TSP), considered the most cost-effective approach, involving the analysis of a restricted number of genes in coding regions (exons).

- WES, where there is analysis of all coding regions of the human genome, site of about $85 \%$ of all pathogenic variants.

- Whole genome sequencing (WGS), considered to be the most expensive method yet capable of detecting mutations in coding (exons) and noncoding (introns) regions, as well as copy number variations (CNV) $)^{33,36}$.

The excess information provided by these methods can also be a trap. Sometimes variants detected in WES may not necessarily be related to the patient's disease, representing incidental and/or non-specific findings. The latter, also known as variants of unknown significance (VOUS), represent variants of a gene found in genetic testing without a known functional or health consequence to the proband. The former represents pathogenic mutations related to other diseases not related to the investigated ataxia, such as the identification of a mutation in the BRCA gene 1 related to breast and ovarian cancer, but not to ataxia. In these cases, it is important to explain to patients and obtain a consent form on the possible risks associated with the incidental findings of genes predisposing to other potentially serious diseases ${ }^{37,38}$ before starting the genetic test. In this context, it is important to highlight the need of gathering clinical data to determine the most likely types of SCA to be investigated in a specific patient ${ }^{5}$.

Other limitations of WES are: failure to effectively identify nucleotide repeat expansions (the major cause of SCA), as well as mutations in GC-rich regions, mitochondrial DNA variants and copy number variations (CNV). They are also subject to sequential reading errors and technical problems such as insufficient depth and coverage ${ }^{34}$.

Thus, the current recommendations are to search for nucleotide repeat expansions most associated with SCA by the PCR technique initially, taking into account the phenotype and epidemiological contexts. However, after ruling out this as a cause, another 70 genes associated with different forms of ataxias may be involved ${ }^{39}$. Therefore, if the initial results are negative, alternative methods for diagnosis, such as NGS, should be considered.

\section{THE USE OF NEXT GENERATION SEQUENCING: EVIDENCE OF LITERATURE}

Recent studies have shown encouraging results of NGS when confirming diagnosis in patients with hereditary ataxia. Pyle et al. ${ }^{40}$ found pathogenic variants in $41 \%$ of patients without diagnosis in 22 families, using the WES method. Efficacy was similar between patients with early onset ( $<20$ years) and late onset ( $>20$ years). Although there was criticism of this study ${ }^{41}$, it revealed the potential impact of WES in patients with hereditary ataxias at any age.

In contrast, Németh et al. ${ }^{41}$ showed that the TSP method identified $18 \%$ of cases in a similar cohort. Larger sequencing of the genome is the likely explanation for the superior results of the study by Pyle et al. Since it allowed the detection of mutations in genes that, although known to cause ataxia, are not considered "ataxia genes" and are therefore not usually included in the gene panels ${ }^{39,41}$.

Meanwhile, Fogel et al. ${ }^{42}$ used WES and identified a percentage similar to that found by Németh, with $21 \%$ of cases identified (16/76) in patients with late-onset cerebellar ataxia, predominantly sporadic.

In a prospective study with patients with progressive cerebellar ataxia, Hadjivassiliou et al.$^{43}$ investigated 146 patients with TSP and identified mutation in $32 \%$ of cases. In another study with 412 patients with a negative molecular diagnosis of ataxia, Coutelier et al. ${ }^{44}$ performed TSP combined with PCR, finding relevant genetic variants in $14.3 \%$ of the cases. The same group carried out another study with 319 patients with cerebellar ataxia, with no history compatible with autosomal dominant pattern and undiagnosed, using $\mathrm{WES}^{45}$. Relevant genetic variants were identified in $28.5 \%$ of the cases $(22.6 \%$ with definitive diagnosis and $6 \%$ with a possible pathogenic variant). In this cohort, younger patients ( $<25$ years) with a history of consanguinity were associated with better chances of diagnosis, which had been previously demonstrated ${ }^{46,47,48}$. Table 5 summarizes the main mutations found in these studies ${ }^{40,41,42,43,44,45}$.

Table 5. Main mutations found with next-generation sequencing technology.

\begin{tabular}{|c|c|}
\hline Authors & Genes mutations \\
\hline $\begin{array}{l}\text { Coutelier } \\
\text { et al. }{ }^{44}\end{array}$ & $\begin{array}{l}\text { CACNA1A ( } 16 \text { cases); Del. ITPR1 ( } 11 \text { cases); } \\
\text { SPG } 7 \text { ( } 9 \text { cases), AFG3L2 ( } 7 \text { cases) }\end{array}$ \\
\hline $\begin{array}{l}\text { Hadjivassiliou } \\
\text { et al. } 43\end{array}$ & $\begin{array}{l}\text { CACNA1A ( } 11 \text { cases), PRKCG ( } 5 \text { cases), } \\
\text { SPTBN2 ( } 4 \text { cases), SPG } 7 \text { ( } 4 \text { cases) }\end{array}$ \\
\hline $\begin{array}{l}\text { Coutelier } \\
\text { et al. }{ }^{45}\end{array}$ & $\begin{array}{c}\text { SPG } 7 \text { ( } 14 \text { cases); SACS (8 cases); SEXT } \\
\text { (7 cases), SYNE } 1 \text { ( } 6 \text { cases), CACNA1A ( } 6 \text { cases) }\end{array}$ \\
\hline Németh et al. ${ }^{41}$ & $\begin{array}{l}\text { SEXT ( } 2 \text { cases), TTBK2 ( } 1 \text { case), PRKCG } \\
\text { (1 case), MRE11A ( } 1 \text { case), SACS ( } 1 \text { case) }\end{array}$ \\
\hline Fogel et al. ${ }^{42}$ & SYNE 1 (3 cases), SPG 7 (2 cases) \\
\hline Pyle et al..$^{40}$ & $\begin{array}{l}\text { SPG } 7 \text { ( } 3 \text { cases), SACS ( } 3 \text { cases), } \\
\text { NPC1 ( } 2 \text { cases), TUBB4A ( } 2 \text { cases) }\end{array}$ \\
\hline
\end{tabular}


These studies have demonstrated that NGS technologies play a crucial role in the diagnosis confirmation of ADCA, leading not only to a decrease in the time of diagnosis of patients, but also in the correlation of the genotypic-phenotypic spectrum, a source of discovery of new genes that cause ataxia, whether unpublished ${ }^{49}$ or not previously associated with ataxia ${ }^{39}$. It is important to point out that the studies have heterogeneous populations, and a comparison between them may be statistically inappropriate.

\section{STRENGTHS AND PITFALLS OF WHOLE EXOME SEQUENCING AND TARGET SEQUENCING PANEL}

TSP are considered a faster and cheaper method when compared to WES, the former representing a useful tool to identify mutations outside the exons, decreasing VOUS and incidental findings, which are important limitations of WES. In addition, it provides more concise information, which can be complemented with confirmatory methods, such as Sanger's sequencing, which fills any data gaps unread by $\mathrm{TSP}^{33}$. The great limitation of TSP method is the need to formulate a genetic panel compatible with the phenotype and family history presented by the patient, which depends exclusively on previously reported clinical findings for the selection of genes, which may allow the escape of more rare genes, linked to atypical presentations or new mutations ${ }^{35,42}$. In addition, new TSP designs are needed as new genes are described.

On the other hand, in WES there is a broad genetic evaluation, without the need for previous clinical information. This allows the discovery of novel genotypic-phenotypic associations, extension of the phenotypic spectrum of a particular gene or recognition of very rare diseases or new mutations ${ }^{39}$. In addition, it can detect about 100-fold more genes compared to the mean detected by diagnostic panels (100-200 genes). It is an excellent tool for patients with hereditary ataxia, considering the great phenotypic and genotype heterogeneity of these patients ${ }^{43}$.

Another advantage of WES is the possibility of reanalysis of the previously obtained data as new genes are discovered and disseminated in the scientific community, enabling a retrospective diagnosis ${ }^{34}$ and reducing time and costs compared to TSP.

Among the problems related to WES we can mention:

- Poorly effective for the diagnosis of nucleotide replications, mutations in GC-rich regions, variants in mitochondrial DNA, structural variations of DNA, mutations in non-coding regions (intronic mutations).

- Incidental and undesired finding of genetic mutations predisposing to cancer, Alzheimer's or other degenerative diseases.

- Generation of large number of variants, which requires the sequencing of family members to "filter" variants of uncertain meaning, reducing specificity and increasing the cost of the procedure.

- To establish a genotypic-phenotypic relationship of a new or non-associated variant prior to ataxia through bioinformatics processing, which may be highly complex.

- Technical problems, such as reading errors, coverage and insufficient depth - the most commonly problem associated with loss of variant detection - may compromise results $^{34,40,41,50}$.

WGS is a method that was restricted to research centers, however, it has been more and more used in the routine of genetic laboratories worldwide. It is known that WGS has a much broader coverage of coding regions compared to WES, as well as covering non-coding regions. However, the amount of information generated may require a lot of time for analysis, considered highly complex, and the cost is much higher than WES. Also, WGS have the same limitation of WES and TSP in detecting repeat expansions ${ }^{50}$. Figures 1,2 and 3 summarize the main advantages and disadvantages of the NGS methods ${ }^{34,35,36,39,42,45,47,50,51}$.

It is important to note that although some studies points WGS to be a cost-effective approach ${ }^{46}$, it is still an expensive and unavailable method for most patients in Brazil.

\section{SHORT TANDEM REPEAT EXPANSIONS AND NGS: SOLUTIONS}

As mentioned throughout the text, NGS methods are not suitable for STR identification. This is due to the fact that currently available methods perform short readings (about 150bp per reading) and the STR expansions responsible for SCA, with few exceptions, usually have expansions that go beyond this limit.

In order to solve this problem, in recent years analysis methods have been developed, such as ExpansionHunter ${ }^{52}$, exSTRa $^{53}$, STRetch ${ }^{54}$ and TREDPARSE ${ }^{55}$, which applied together with NGS, are capable of detecting STR expansions where the expanded allele size is greater than the length of standard short-read sequencing reads.

In the past, there were other detection methods for STR, such as HipSTR and LobSTR, but both have the limitation of detecting only STR alleles with repeat lengths smaller than the read length employed in the sequencing. All methods except exSTRa perform better when are applied to a WGS platform, preferably PCR free, where library preparation protocols yield the best data to allow repeat expansion detection, although platforms such as WES provide enough data to detect expansions in STR loci.

Dashnow et al demonstrated the use of STRetch in four patients without diagnosis after screening for most common expansions (SCA1-3, SCA 6, SCA 12, SCA 17 and DRPLA) and use of WGS screening for SNV. STRetch was capable of 


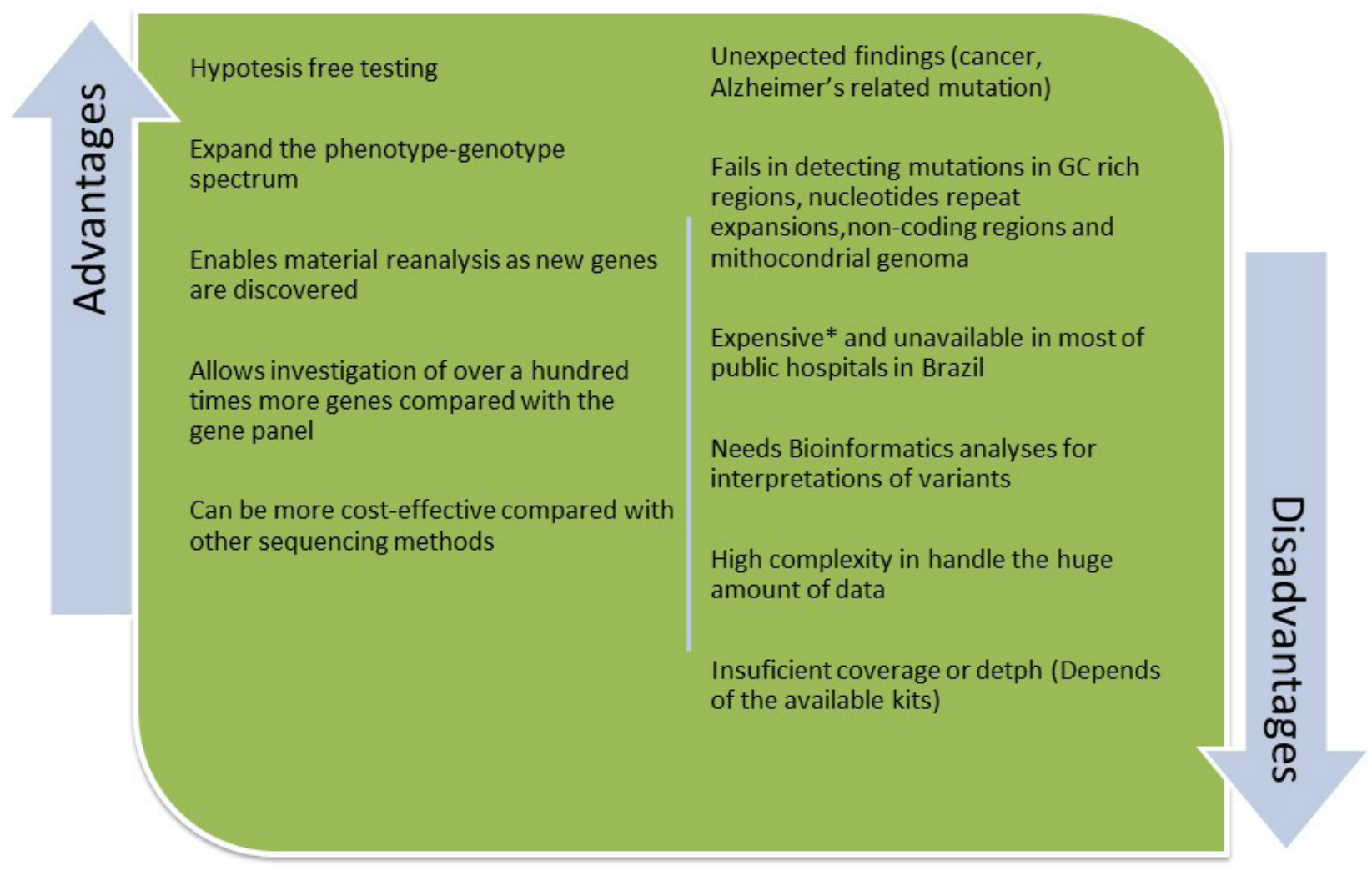

Figure 1. Whole exome sequencing $34,35,36,39,42,45,47,50,51$.

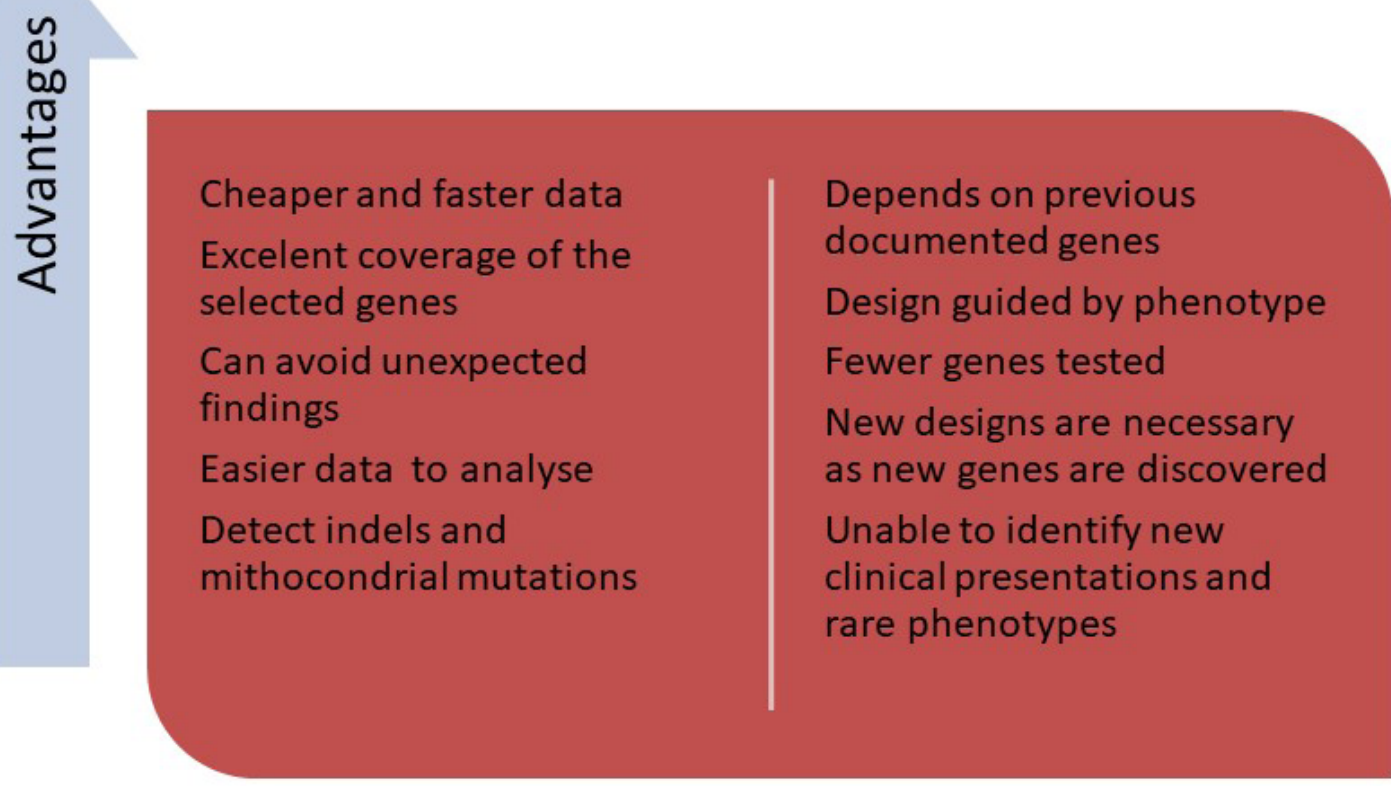

Figure 2. Target sequencing panel ${ }^{34,35,36,39,42,45,47,50,51}$. 


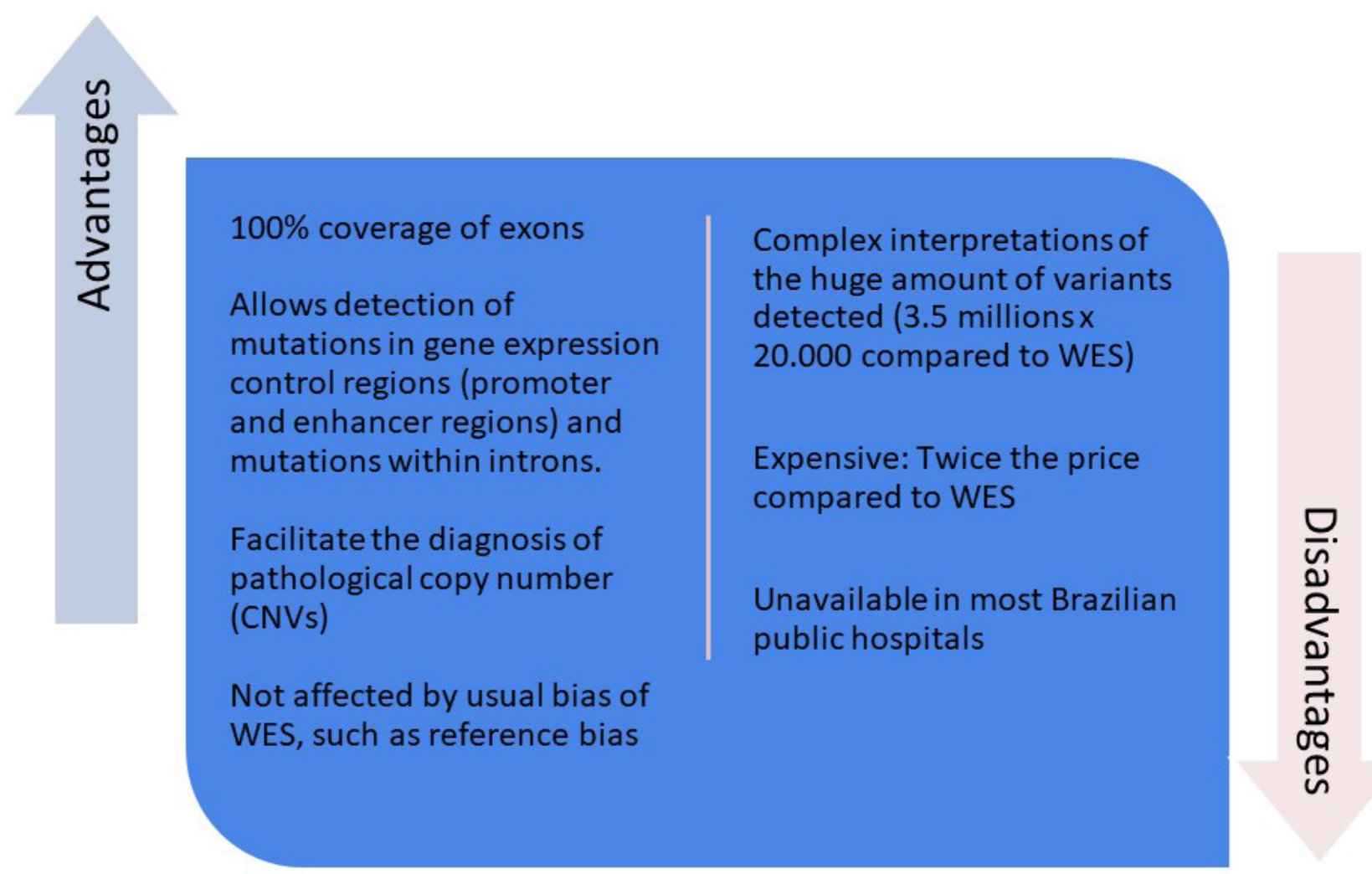

Figure 3. Whole genome sequencing $34,35,36,39,42,45,47,50,51$.

identifying a SCA 8 expansion in one patient, confirmed by $\mathrm{PCR}^{56}$. Tankard et al. compared all four methods in different NGS platforms for detection of expansions of tandem repeat, and showed good sensitivity and specificity for all of them ( $>87$ and $>97 \%$, respectively, when the methods were applied with WGS PCR free platform) and none of them were better than the other, suggesting that the use of all existing methods could be advantageous, improving the accuracy of the results $^{57}$. Each of these alternative methods has its own technical advantages and disadvantages that goes beyond the scope of this review and must be seen elsewhere.

Although these techniques can detect novel repeat expansions, all of them rely on a priori knowledge of STR loci to be examined, that can be assembled by using annotation of STRs from Tandem Repeats Finder results. Hence, de novo mutation cannot be detected by these techniques yet. Furthermore, some STR loci are poorly captured due to their extreme GC content, such as repeat expansions alleles underlying FRAXA (FMR1), FRAXE (FRM2) and FTDALS1 (C9orf72). Despite these limitations, several authors recommend their implementation in routine screening with NGS ${ }^{58}$.

It's important to remember that gold-standard techniques for diagnosis of STR expansion, such as Southern blots and TP-PCR (Tripled Primed PCR) shouldn't be abandoned. The new NGS technique are considered screening methods, requiring validation with gold-standard methods.
Southern Blot or TP-PCR are still the most accurate methods for detecting STR expansions and the size of the expanded allele, including whether there are interruptions, which has prognostic implications for age of onset, disease progression, and outcome $e^{57,58}$.

\section{LONG READ SEQUENCING: A FUTURE NOT SO DISTANT}

Sometimes even after extensive investigation with NGS short-read technologies the diagnose remains unknown. This is particularly true in cases with complex expanded alleles ${ }^{58,59}$, where the repeat may be interrupted multiple times. In this case, long read sequencing could be useful. These technologies, such as PacBio and Nanopore sequencing are gaining notoriety and drawing interest in bioinformatics. Readings can reach tens of thousands in comparison with few hundreds in short-readings NGS. Rather than estimating an STR expansion, the LRS will capture the entire expanded allele in a read fragment, providing more accurate information about that expansion. While encouraging, LRS is still considered very expensive (about 10x more compared to conventional NGS methods) and is therefore not cost effective for routine use ${ }^{57,58}$. However, this should change soon when LRS will be a valuable tool for the diagnosis of Mendelian diseases such as ADCA. 


\section{CONCLUSION}

Hereditary ataxias are a complex group of diseases from a clinical and genetic point of view. About $30 \%$ of patients with ADHA remain undiagnosed after an initial investigation into the most common gene variants. Guidelines for the investigation of SCA recommend that the initial investigation be done according to the phenotypic characteristics and family history, which may favor one type of SCA compared to others ${ }^{60,61}$.

Although there are limitations, studies have shown that the use of NGS may be useful in the investigation of patients with undiagnosed ataxias. The most common mutations related to SCA are due to the expansion of nucleotides, which is a limiting factor in NGS technologies. However, in the context of a negative molecular diagnosis of ataxias, several other molecular variants such as deletions, missense, nonsense and splice mutations (SCA 5, 11, 13, 14, 15/16 and 27), mutations in non-coding regions (SCA 8,10 and 12) or mutations associated with other diseases such as spastic paraplegias, recessive ataxias, and channelopathies, may be responsible. In these cases, and NGS have proven effective in accelerating the diagnostic process.

Furthermore, new techniques for detections of STR expansions with NGS, such as exSTRa, STRetch, ExpansionHunter and TREDPARSE, are proving to be valuable tools in diagnosing STR related diseases, which includes SCA ${ }^{56,57,58}$. Long read sequencing it's another promising diagnostic method for mendelian diseases, but it's not widely available and it's too expensive for routine use in clinical practice.

The unbridled evolution of neurogenetic research may answer many current questions soon enough.

\section{References}

1. Durr A. Autosomal dominant cerebellar ataxias: polyglutamine expansions and beyond. Lancet Neurol. 2010 Sep;9(9):885-94. http:// dx.doi.org/10.1016/S1474-4422(10)70183-6

2. Schöls L, Amoiridis G, Büttner T, Przuntek H, Epplen JT, Riess 0 . Autosomal dominant cerebellar ataxia: Phenotype differences in genetically defined subtypes? Ann Neurol. 1997 Dec;42(6):924-32. https://doi.org/10.1002/ana.410420615

3. Schöls L, Bauer P, Schmidt T, Schulte T, Riess O. Autosomal dominant cerebellar ataxias: clinical features, genetics, and pathogenesis. Lancet Neurol. 2004 May;3(5):291-304. https://doi.org/10.1016/ S1474-4422(04)00737-9

4. Harding AE. The clinical features and classification of the late onset autosomal dominant cerebellar ataxias. A study of 11 families, including descendants of the 'the Drew family of Walworth'. Brain. 1982 Mar;105(Pt 1):1-28. https://doi.org/10.1093/brain/105.1.1

5. Juvonen V, Hietala M, Kairisto V, Savontaus ML. The occurrence of dominant spinocerebellar ataxias among 251 Finnish ataxia patients and the role of predisposing large normal alleles in a genetically isolated population. Acta Neurol Scand. 2005 Mar;111(3):154-62. https://doi.org/10.1111/j.1600-0404.2005.00349.x

6. Sullivan R, Yau WY, O'Connor E, Houlden H. Spinocerebellar ataxia: an update.J Neurol. 2019 Feb;266(2):533-44. https://doi.org/10.1007/ s00415-018-9076-4

7. Gennarino VA, Palmer EE, McDonell LM, Wang L, Adamski CJ, Koire $A$, et al. A mild PUM1 mutation is associated with adult-onset ataxia, whereas haploinsufficiency causes developmental delay and seizures. Cell. 2018 Feb;172(5):924-36.e11. https://doi.org/10.1016/j. cell.2018.02.006

8. Genis D, Ortega-Cubero S, San Nicolás H, Corral J, Gardenyes $J$, de Jorge L, et al. Heterozygous STUB1 mutation causes familial ataxia with cognitive affective syndrome (SCA48). Neurology. 2018 Nov;91(21):e1988-98. https://doi.org/10.1212/ WNL.0000000000006550

9. Ruano L, Melo C, Silva MC, Coutinho P. The global epidemiology of hereditary ataxia and spastic paraplegia: a systematic review of prevalence studies Neuroepidemiology. 2014;42(3):174-83. https:// doi.org/10.1159/000358801

10. van de Warremburg BP, Sinke RJ, Verschuuren-Bemelmans CC, Scheffer $H$, Brunt ER, Ippel PF, et al. Spinocerebellar ataxias in the Netherlands: prevalence and age at onset variance analysis. Neurology. 2002 Mar;58(5):702-8. https://doi.org/10.1212/wnl.58.5.702
11. Erichsen AK, Koht J, Stray-Pedersen A, Abdelnoor M, Tallaksen CM. Prevalence of hereditary ataxia and spastic paraplegia in southeast Norway: a population-based study. Brain. 2009 Jun;132(Pt 6):1577-88. https://doi.org/10.1093/brain/awp056

12. Coutinho P, Ruano L, Loureiro JL, Cruz VT, Barros J, Tuna A, et al. Hereditary ataxia and spastic paraplegia in Portugal: a populationbased prevalence study. JAMA Neurol. 2013 Jun;70(6):746-55. https://doi.org/10.1001/jamaneurol.2013.1707

13. Storey E, du Sart D, Shaw J, Lorentzos P, Kelly L, McKinley Gardner R, et al. Frequency of spinocerebellar ataxia types 1, 2, 3, 6, and 7 in Australian patients with spinocerebellar ataxia. Am J Med Genet. 2000 Dec;95(4):351-7. https:// doi.org/10.1002/1096-8628(20001211)95:4\%3C351::aidajmg10\%3E3.0.co;2-r

14. Brusco A, Gellera C, Cagnoli C, Saluto A, Castucci A, Michielotto $\mathrm{C}$, et al. Molecular genetics of hereditary spinocerebellar ataxia: mutation analysis of spinocerebellar ataxia genes and CAG/CTG repeat expansion detection in 225 Italian families. Arch Neurol. 2004 May;61(5):727-33. https://doi.org/10.1001/archneur.61.5.727

15. Alonso E, Martínez-Ruano L, De Biase I, Mader C, Ochoa A, Yescas P, et al. Distinct distribution of autosomal dominant spinocerebellar ataxia in the Mexican population. Mov Disord. 2007 May;22(7):1050-3. http://dx.doi.org/10.1002/mds.21470

16. Velázquez-Pérez L, Santos FN, García R, Paneque HM, Hechavarría PR. Epidemiology of Cuban hereditary ataxia. Rev Neurol. 2001 Apr;32(7):606-11.

17. Tang B, Liu C, Shen L, Dai H, Pan Q, Jing L, et al. Frequency of SCA1, SCA2, SCA3/MJD, SCA6, SCA7, and DRPLA CAG trinucleotide repeat expansion in patients with hereditary spinocerebellar ataxia from Chinese kindreds. Arch Neurol. 2000 Apr;57(4):540-4. https://doi. org/10.1001/archneur.57.4.540

18. Watanabe H, Tanaka F, Matsumoto M, Doyu M, Ando T, Mitsuma T, et al. Frequency analysis of autosomal dominant cerebellar ataxias in Japanese patients and clinical characterization of spinocerebellar ataxia type 6. Clin Genet. 1998 Jan;53(1):13-9. https://doi. org/10.1034/j.1399-0004.1998.531530104.x

19. Juvonen V, Hietala M, Kairisto V, Savontaus ML. The occurrence of dominant spinocerebellar ataxias among 251 Finnish ataxia patients and the role of predisposing large normal alleles in a genetically isolated population. Acta Neurol Scand. 2005 Mar;111(3):154-62. https://doi.org/10.1111/j.1600-0404.2005.00349.x 
20. Srivastava AK, Choudhry S, Gopinath MS, Roy S, Tripathi M, Brahmachari SK, et al. Molecular and clinical correlation in five Indian families with spinocerebellar ataxia 12. Ann Neurol. 2001 Dec;50(6):796-800. https://doi.org/10.1002/ana.10048

21. Jardim LB, Pereira ML, Silveira I, Ferro A, Sequeiros J, Giugliani R. Neurologic findings in Machado-Joseph disease. Relation with disease duration, subtypes, and (CAG). Arch Neurol. 2001 Jun;58(6):899-904. https://doi.org/10.1001/archneur.58.6.899

22. Cintra VP, Lourenço CM, Marques SE, Oliveira LM, Tumas V, Marques Junior W. Mutational screening of 320 Brazilian patients with autosomal dominant spinocerebellar ataxia. J Neurol Sci. 2014 Oct;347(1-2):375-9. https://doi.org/10.1016/j.jns.2014.10.036

23. Teive HAG, Munhoz RP, Arruda WO, Lopes-Cendes I, Raskin S, Werneck LC, et al. Spinocerebellar ataxias: genotype-phenotype correlations in 104 Brazilian families. Clinics. 2012;67(5):443-9. https://doi.org/10.6061/clinics/2012(05)07

24. Rangel DM, Nóbrega PR, Braga-Neto P, Saraiva-Pereira ML, Jardim LB, Braga-Neto P. A case series of hereditary ataxias in a highly cosanguineous population from Northeast Brazil. Parkinsonism Relat Disord. 2019 Apr;61:193-7. https://doi.org/10.1016/j. parkreldis.2018.10.027

25. de Castilhos RM, Furtado GV, Gheno TC, Schaeffer P, Russo A, Barsottini O, et al. Spinocerebellar ataxias in Brazil - frequencies and modulating effects of related genes. Cerebellum. 2014 Feb;13(1):17-28. https://doi.org/10.1007/s12311-013-0510-y

26. Nascimento FA, Rodrigues VOR, Pelloso FC, Camargo CHF, Moro A, Raskin S, et al. Spinocerebellar ataxias in Southern Brazil: Genotypic and phenotypic evaluation of 213 families. Clin Neurol Neurosurg 2019; Sep; 184: 105427. https://doi.org/10.1016/j. clineuro.2019.105427

27. Braga-Neto P, Pedroso JL, Furtado GV, Gheno TC, Saraiva-Pereira ML, Jardim LB, et al. Dentatorubro-Pallidoluysian Atrophy (DRPLA) among 700 families with ataxia in Brazil. Cerebellum. 2017 Aug;16(4):812-6. https://doi.org/10.1007/s12311-017-0862-9

28. Silveira I ${ }^{1}$, Lopes-Cendes I, Kish S, Maciel P, Gaspar C, Coutinho P, et al. Frequency of spinocerebellar ataxia type 1, dentatorubropallidoluysian atrophy, and Machado-Joseph disease mutations in a large group of spinocerebellar ataxia patients. Neurology. 1996 Jan;46(1):214-8.

29. Lopes-Cendes I, Teive HG, Calcagnotto ME, Da Costa JC, Cardoso F, Viana E, et al. Frequência das diferentes mutações causadoras de ataxia espinocerebelar (SCA1, SCA2, MJD / SCA3 e DRPLA) em um grande grupo de pacientes brasileiros. Arq Neuropsiquiatr. 1997 Sep;55(3B):519-29.

30. A Trott, LB Jardima, HT Ludwiga, JAM Sautea, O Artigala's, et al. Letter to the editor: Spinocerebellar ataxias in 114 Brazilian families: clinical and molecular findings. Clin Genet. 2006;70:173-6. https:// doi.org10.1111/j.1399-0004.2006.00656.x

31. Freund AA, Scola RH, Teive HA, Arndt RC, Costa-Ribeiro MC, Alle LF, Werneck LC. Microsatellite and allele frequency in unaffected and affected individuals. Arq Neuropsiquiatr. 2009;67(4):1124-32.

32. Subramony SH, Filla A. Autosomal dominant spinocerebellar ataxias ad infinitum? Neurology. 2001 Feb;56(3):287-9. https://doi. org/10.1212/wnl.56.3.287

33. Sanger F, Nicklen S, Coulson AR. DNA sequencing with chain-terminating inhibitors. Proc Natl Acad Sci U S A. 1977 Dec;74(12):5463-7. https://doi.org/10.1073/pnas.74.12.5463

34. Hui P. Next generation sequencing: chemistry, technology and applications. Top Curr Chem. 2014;336:1-18. https://doi. org/10.1007/128_2012_329

35. Galatolo D, Tessa A, Filla A, Santorelli FM. Clinical application of next generation sequencing in hereditary spinocerebellar ataxia: increasing the diagnostic yield and broadening the ataxia-spasticity spectrum. A retrospective analysis. Neurogenetics. 2018 Jan;19(1):18. https://doi.org/10.1007/s10048-017-0532-6

36. Xue Y, Ankala A, Wilcox WR, Hegde MR. Solving the molecular diagnostic testing conundrum for Mendelian disorders in the era of next-generation sequencing: single-gene, gene panel, or exome/ genome sequencing. Genet Med. 2015;17(6):444-51. https://doi. org/10.1038/gim.2014.122

37. Marelli C, Guissart C, Hubsch C, Renaud M, Villemin JP, Larrieu L, et al. Mini-exome coupled to read-depth based copy number variation analysis in patients with inherited ataxias. Hum Mutat. 2016 Dec;37(12):1340-53. https://doi.org/10.1002/humu.23063

38. Bamshad MT, Ng SB, Bigham AW, Tabor HK, Emond MJ, Nickerson DA. Exome sequencing as a tool for Mendelian disease gene discovery. Nat Rev Genet. 2011 Sep;12(11):745-55. https://doi. org/10.1038/nrg303

39. van de Warrenburg B, Schouten M, de Bot S, Vermeer S, Meijer R, Pennings $M$, et al. Clinical exome sequencing for cerebellar ataxia and spastic paraplegia uncovers novel gene-disease associations and unanticipated rare disorders. Eur J Hum Genet. 2017 Mar;25(3):393-0. https://doi.org/10.1038/ejhg.2016.168

40. Pyle A, Smertenko T, Bargiela D, Helen Griffin, Jennifer Duff, Marie Appleton, et al. Exome sequencing in undiagnosed inherited and sporadic ataxias. Brain. 2015 Feb;138(2):276-83. https:// doi. org/10.1093/brain/awu348

41. Németh AH, Kwasniewska AC, Lise S, Parolin Schnekenberg R, Becker EB, Bera KD, et al. Next generation sequencing for molecular diagnosis of neurological disorders using ataxias as a model. Brain. 2013 Oct;136(Pt 10):3106-18. https://doi.org/10.1093/brain/awt236

42. Fogel B, Lee H, Deignan J, Strom SP, Kantarci S, Wang X, et al. Exome sequencing in the clinical diagnosis of sporadic or familial cerebellar ataxia. JAMA Neurol. 2014 Oct;71(10):1237-46. https://doi. org/10.1001/jamaneurol.2014.1944

43. Hadjivassiliou M, Martindale J, Shanmugarajah P, Grünewald RA, Sarrigiannis PG, Beauchamp N, et al. Causes of progressive cerebellar ataxia: prospective evaluation of 1500 patients. J Neurol Neurosurg Psychiatry. 2017 Apr;88(4):301-9. https://doi.org/10.1136/ jnnp-2016-314863

44. Coutelier M, Coarelli G, Monin ML, Konop J, Davoine CS, Tesson C, et al. A panel study on patients with dominant cerebellar ataxia highlights the frequency of channelopathies. Brain. 2017 Jun;140(6):1579-94. https://doi.org/10.1093/brain/awx081

45. Coutelier M, Hammer MB, Stevanin G, Monin ML, Davoine C, Mochel $F$, et al. Efficacy of exome targeted capture sequencing to detect mutations in known cerebellar ataxia genes. JAMA Neurol. 2018 May;75(5):591-9. https://doi.org/10.1001/jamaneurol.2017.5121

46. Sawyer SL, Schwartzentruber J, Beaulieu CL, Dyment D, Smith A, Warman Chardon J, et al. Exome sequencing as a diagnostic tool for pediatric-onset ataxia. Hum Mutat. 2014 Jan;35(1):45-9. https://doi. org/10.1002/humu.22451

47. Iqbal Z, Rydning SL, Wedding IM, Koht J, Pihlstrøm L, Rengmark AH, et al. Targeted high throughput sequencing in hereditary ataxia and spastic paraplegia. PLoS One. 2017 Mar;12(3):e0174667. https://doi. org/10.1371/journal.pone.0174667

48. Ohba C, Osaka H, lai M, Yamashita S, Suzuki Y, Aida N, et al. Diagnostic utility of whole exome sequencing in patients showing cerebellar and/or vermis atrophy in childhood. Neurogenetics. 2013 Oct;14(3-4):225-32. https://doi.org/10.1007/s10048-013-0375-8

49. Wang JL, Yang X, Xia K, Hu ZM, Weng L, Jin X, et al. TGM6 identified as a novel causative gene of spinocerebellar ataxias using exome sequencing. Brain. 2010 Dec;133(Pt 12):3510-8. https://doi. org/10.1093/brain/awq323

50. Pena L, Jiang YH, Schoch K, Spillmann RC, Walley N, Stong N, et al. Looking beyond the exome: a phenotype-first approach to molecular diagnostic resolution in rare and undiagnosed diseases Genet Med. 2018 Apr;20(4):464-9. https://doi.org/10.1038/ gim. 2017.128

51. Lelieveld SH, Spielmann M, Mundlos S, Veltman JA, Gilissen C. Comparison of exome and genome sequencing technologies for the complete capture of protein-coding regions. Hum Mutat. 2015 Aug;36(8):815-22. https://doi.org/10.1002/humu.22813 
52. Dolzhenko E, van Vugt JJFA, Shaw RJ, Bekritsky MA, van Blitterswijk M, Narzisi G, et al. Detection of long repeat expansions from PCR-free whole-genome sequence data. Genome Res. 2017 Nov;27(11):1895-903. https://doi.org/10.1101/ gr.225672.117

53. Tankard RM, Delatycki MB, Lockhart PJ, Bahlo M. Detecting known repeat expansions with standard protocol next generation sequencing, towards developing a single screening test for neurological repeat expansion disorders. bioRxiv. 2017 Jun:1-15. https://doi.org/10.1101/157792

54. Dashnow H, Lek M, Phipson B, Halman A, Sadedin S, Lonsdale A, et al. STRetch: detecting and discovering pathogenic short tandem repeat expansions. Genome Biol. 2018;19:121. https://doi. org/10.1186/s13059-018-1505-2

55. Tang H, Kirkness EF, Lippert C, Biggs WH, Fabani M, Guzman E, et al. Profiling of short-tandem-repeat disease alleles in 12,632 human whole genomes. Am J Hum Genet. 2017 Nov;101(5):700-15. https:// doi.org/10.1016/j.ajhg.2017.09.013

56. Dashnow H, Lek M, Phipson B, Halman A, Sadedin S, Lonsdale A, et al. STRetch: Detecting and discovering pathogenic short tandem repeat expansions. Genome Biol. 2018;19:121.
57. Tankard RM, Bennett MF, Degorski P, Delatycki MB, Lockhart PJ, Bahlo M. Detecting expansions of tandem repeats in cohorts sequenced with short-read sequencing data. Am J Hum Genet. 2018 Dec;103(6):858-73. https://doi.org/10.1016/j.ajhg.2018.10.015

58. Bahlo M, Bennett MF, Degorski P, Tankard RM, Delatycki MB, Lockhart PJ. Recent advances in the detection of repeat expansions with short-read next-generation sequencing. F1000Res. 2018 Jun 13;7. https://doi.org/10.12688/f1000research.13980.1

59. de Leeuw R, Garnier D, Kroon RMJM, Horlings CGC, de Meijer E, Buermans $\mathrm{H}$, et al. Diagnostics of short tandem repeat expansion variants using massively parallel sequencing and componential tools. Eur J Hum Genet. 2019 Mar;27:400-7. https://doi.org/10.1038/ s41431-018-0302-4

60. Gasser T, Finsterer J, Baets J, Van Broeckhoven C, Di Donato S, Fontaine B, et al. EFNS guidelines on the molecular diagnosis of ataxias and spastic paraplegias. Eur J Neurol. 2010 Feb;17(2):179-88. https://doi.org/10.1111/j.1468-1331.2009.02873.x

61. de Silva R, Greenfield J, Cook A, Bonney H, Vallortigara J, Hunt B, et al. Guidelines on the diagnosis and management of the progressive ataxias. Orphanet J Rare Dis. 2019;14:51. https://doi.org/10.1186/ s13023-019-1013-9 